\title{
Prevalence of Physical Activity among Adolescents from 105 Low, Middle, and High-Income Countries
}

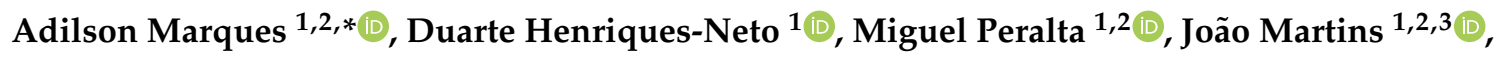 \\ Yolanda Demetriou ${ }^{4}$ (D), Dorothea M. I. Schönbach ${ }^{4}$ (D) and Margarida Gaspar de Matos ${ }^{2,5}$ \\ 1 Centro Interdisciplinar de Estudo da Performance Humana, Faculdade de Motricidade Humana, \\ Universidade de Lisboa, 1499-002 Lisboa, Portugal; duarteneto@campus.ul.pt (D.H.-N.); \\ mperalta@fmh.ulisboa.pt (M.P.); jmartins@fmh.ulisboa.pt (J.M.) \\ 2 Instituto de Saúde Ambiental, Universidade de Lisboa, 1649-028 Lisboa, Portugal; mmatos@fmh.ulisboa.pt \\ 3 Laboratório de Pedagogia, Faculdade de Motricidade Humana e UIDEF, Instituto de Educação, \\ Universidade de Lisboa, 1649-013 Lisboa, Portugal \\ 4 Department of Sport and Health Sciences, Technical University of Munich, 80333 Munich, Germany; \\ yolanda.demetriou@tum.de (Y.D.); dorothea.schoenbach@tum.de (D.M.I.S.) \\ 5 Faculdade de Motricidade Humana, Universidade de Lisboa, 1499-002 Lisboa, Portugal \\ * Correspondence: amarques@fmh.ulisboa.pt; Tel.: +351-214-149-100
}

Received: 11 April 2020; Accepted: 29 April 2020; Published: 30 April 2020

\begin{abstract}
Introduction: Physical activity (PA) is a beneficial health behaviour, however most adolescents worldwide are physically inactive. Updated information on the prevalence and trends of PA is important to inform national and international authorities and support countries' public health policies and actions. This study aimed to present the worldwide, regional, and national prevalence of PA participation according to its frequency in adolescents. Methods: This study is based on cross-sectional surveys of adolescents' populations from several countries and all regions worldwide. The sample comprised 520,533 adolescents (251,788 boys; 268,745 girls), from 105 countries and regions. Results: Most adolescents engaged in PA up to 3 days/week (57.1\%; 95\% CI: 56.9; 57.2). The prevalence of engaging in PA every day decreases over the age from $28.2 \%$ at age of $11-12$ years (95\% CI: $27.4 ; 29.0$ ) to $21.2 \%$ at age of $16-17$ years (95\% CI: $20.3 ; 22.0$ ) among boys; and from $19.4 \%$ (95\% CI: $18.5 ; 20.2)$ to $11.1 \%(95 \%$ CI: $10.1 ; 12.0)$ among girls. For boys and girls who engaged in PA 5-6 days/week, the prevalence increases from countries with the lowest human development index to countries with the highest. Cambodia (7.3\%, 95\% CI: 3.8; 10.8), Philippines (7.7\%, 95\% CI: 5.6; 9.7), Sudan (8.8\%, 95\% CI: 4.7; 12.9), Timor-Leste (8.9\%, 95\% CI: 5.5; 12.3), and Afghanistan (10.1\%, 95\% CI: 6.1; 14.1) were the countries with the lowest prevalence of sufficient PA. Conclusions: National, regional, and worldwide data on the prevalence of physical activity in adolescents highlights the importance of improving the global levels of PA, especially in girls. Identifying the factors causing the age-related decrease in physical activity levels will permit public health entities to define priority actions and policies against physical inactivity.
\end{abstract}

Keywords: sports; physical exercise; young people; physical inactivity

\section{Introduction}

Physical activity (PA) is an important health behaviour. Among children and adolescents, PA has a significant impact on cardiovascular, bone, and metabolic health, improving fitness, weight status, and sleep [1]. Besides physical health benefits, there is increasing evidence on the cognitive, psychological, and social benefits of PA [2]. Furthermore, PA benefits obtained during adolescence can be transferred into adulthood [1,3]. To achieve these benefits, adolescents are recommended to engage in moderate-to-vigorous intensity PA at least 60 min every day [4]. 
Promoting PA is of importance to public health. Even if PA recommendations are not attained, major improvements in health can be achieved from modest increases in regular PA [5]. Furthermore, some evidence suggests that those who are below the current public health recommendations benefit more from increases in PA than those who are already within the recommendations [1]. Thus, the public health impact of PA and the potential benefits of even small population-wide increases are considerable [1].

Despite all the health benefits of PA, most adolescents worldwide are physically inactive. It is estimated that $77.6 \%$ of boys and $84.7 \%$ of girls aged 11 to 17 years old are physically inactive [6]. The evidence also suggests that PA declines during adolescent years [6,7]. Updated information on the prevalence and trends of physical inactivity is important to inform national and international authorities and support countries' public health policies and actions. Nonetheless, previous studies focused on the percentage of adolescents who did not practice enough PA to achieve PA recommendations [6-8]. Thus, all adolescents who did not achieve the PA recommendations were grouped in the same group. However, considering in the same group adolescents who do not practice enough PA on any day of the week with adolescents who practice 3 or more days/week for at least 60 min of PA may not be useful for policymakers and public health promoters. Knowledge of PA participation prevalence according to frequency, i.e., times practiced per week, is also crucial as it presents more detailed data and allows for further action and tailored public health strategies in each country. Thus, the aim of this study, using cross-sectional survey data, was to present the worldwide, regional, and national prevalence of PA participation according to its frequency in adolescents aged 11 to 17 years.

\section{Materials and Methods}

\subsection{Participants and Procedures}

This study is based on cross-sectional surveys of adolescents' populations from several countries, from all regions worldwide. Data were collected from representative national sample sizes of at least 100 adolescents, from 105 countries. Data were from national and international surveys, namely the Health Behaviour in School-aged Children (HBSC), the Global School-Based Student Health Survey (GSHS), the Youth Risk Behavior Surveillance (YRBS), the Pesquisa Nacional de Saúde do Escolar (PENSE), and the Encuesta Nacional de Salud y Nutrición (ENSNUT). The final database, with data from all surveys, consisted of 558,443 adolescents. As the surveys did not collect data from adolescents within the same age range, only adolescents aged 11 to 17 years were selected to allow comparison between countries. Adolescents with missing data/non-response on PA were removed from the sample. The final sample comprised 520,533 adolescents (251,788 boys, 268,745 girls) from 105 countries and eight regions.

Data collected in surveys were self-reported. Adolescents were asked to report the number of days they were physically active for a total of at least $60 \mathrm{~min}$ per day in the last 7 days. Answers were given on an 8 -point scale $(0=$ none to $7=$ daily). This is a valid and reliable question assessing adolescents' PA at an epidemiological level [9,10], and it has been used in several studies [6,11-13]. Although the data came from different surveys (HBSC, GSHS, YRBS, PENSE, ENSANUT), it should be noted that in all surveys the same question was used to assess the adolescents' PA levels. Adolescents were provided with a definition of PA accompanied by examples of some age-relevant activities (e.g., running, cycling, dancing, playing football, basketball).

\subsection{Data Analysis}

For the entire sample, descriptive statistics were calculated (percentages and $95 \%$ confidence interval). To estimate the prevalence of PA levels, data were stratified by sex, age (11 to 12 years, 13 to 15 years, 16 to 17 years), eight world regions (1. Central and Eastern Europe, 2. Central Asia, the Middle East, and North Africa, 3. East and southeast, Asia, 4. High-income Western countries, 5. Oceania, 6. Sub-Saharan Africa, 7. South Asia, 8. Latin America and the Caribbean), adapted from 
the World Bank and previous studies [6,14], human development index (HDI) (low, middle, high, very high), and countries [15]. PA was recoded into 1 to 2 days/week, 3 to 4 days/week, 5 to 6 days/week, and every day. The daily practice of moderate to vigorous PA of at least $60 \mathrm{~min}$ was defined as reaching the PA recommendation [4]. Descriptive data are presented as percentages. The prevalence of PA levels was calculated along with a $95 \%$ confidence interval (CI). Data analysis was performed using IBM SPSS Statistics version 25.

\section{Results}

Table 1 presents the sample distribution according to age, HDI, and PA levels. Boys and girls presented different figures. About half of the boys ( $50.1 \%$; $95 \%$ CI: $49.8,50.2)$ engaged in PA up to 3 days/week and for girls, the prevalence was 63.6\% (95\% CI: 63.4, 63.8). For every day PA, boys presented a higher prevalence than girls ( $22.1 \%$; $95 \%$ CI: $21.7,22.4$ vs. $12.6 \%, 95 \%$ CI: $12.2,12.9)$.

Table 1. Participants' characteristics.

\begin{tabular}{|c|c|c|c|c|c|c|}
\hline & \multicolumn{2}{|c|}{ Total $(n=520,533)$} & \multicolumn{2}{|c|}{ Boys $(n=25,1788)$} & \multicolumn{2}{|c|}{ Girls $(n=268,745)$} \\
\hline & $\mathbf{n}$ & $\%(95 \% \mathrm{CI})$ & $\mathbf{n}$ & $\%(95 \%$ CI $)$ & $\mathbf{n}$ & $\%(95 \% \mathrm{CI})$ \\
\hline \multicolumn{7}{|l|}{ Age } \\
\hline 11 years & 55,782 & $10.7(10.5,11.0)$ & 27,153 & $10.8(10.4,11.2)$ & 28,629 & $10.7(10.3,11.0)$ \\
\hline 12 years & 25,609 & $4.9(4.7,5.2)$ & 12,246 & $4.9(4.5,5.2)$ & 13,363 & $5.0(4.6,5.3)$ \\
\hline 13 years & 116,031 & $22.3(22.1,22.5)$ & 54,536 & $21.7(21.3,22.0)$ & 61,495 & $22.9(22.6,23.2)$ \\
\hline 14 years & 116,894 & $22.5(22.2,22.7)$ & 55,184 & $21.9(21.6,22.3)$ & 61,710 & $23.0(22.6,23.3)$ \\
\hline 15 years & 131,520 & $25.3(25.0,25.5)$ & 64,961 & $25.8(25.5,26.1)$ & 66,559 & $24.8(24.4,25.1)$ \\
\hline 16 years & 53,582 & $10.3(10.0,10.6)$ & 27,251 & $10.8(10.5,11.2)$ & 26,331 & $9.8(9.4,10.2)$ \\
\hline 17 years & 21,115 & $4.1(3.8,4.3)$ & 10,457 & $4.2(3.8,4.5)$ & 10,658 & $4.0(3.6,4.3)$ \\
\hline \multicolumn{7}{|l|}{ HDI } \\
\hline Very high & 225,408 & $43.3(43.1,43.5)$ & 110,258 & $43.8(43.5,44.1)$ & 115,150 & $42.8(42.6,43.1)$ \\
\hline High & 185,430 & $35.6(35.4,35.8)$ & 89,604 & $35.6(35.3,35.9)$ & 95,826 & $35.7(35.4,36.0)$ \\
\hline Middle & 87,088 & $16.7(16.5,17.0)$ & 40,249 & $16.0(15.6,16.3)$ & 46,839 & $17.4(17.1,17.8)$ \\
\hline Low & 22,607 & $4.3(4.1,4.6)$ & 11,677 & $4.6(4.3,5.0)$ & 10,930 & $4.1(3.7,4.4)$ \\
\hline \multicolumn{7}{|l|}{ PA } \\
\hline Never & 94,279 & $18.1(17.9,18.4)$ & 37,395 & $14.9(14.5,15.2)$ & 56,884 & $21.2(20.8,21.5)$ \\
\hline 1 days/week & 69,607 & $13.4(13.1,13.6)$ & 29,089 & $11.6(11.2,11.9)$ & 40,518 & $15.1(14.7,15.4)$ \\
\hline 2 days/week & 68,091 & $13.1(12.8,13.3)$ & 29,280 & $11.6(11.3,12.0)$ & 38,811 & $14.4(14.1,14.8)$ \\
\hline 3 days/week & 64,870 & $12.5(12.2,12.7)$ & 30,111 & $12.0(11.6,12.3)$ & 34,759 & $12.9(12.6,13.3)$ \\
\hline 4 days/week & 50,501 & $9.7(9.4,10.0)$ & 25,403 & $10.1(9.7,10.5)$ & 25,098 & $9.3(9.0,9.7)$ \\
\hline 5 days/week & 51,611 & $9.9(9.7,10.2)$ & 27,098 & $10.8(10.4,11.1)$ & 24,513 & $9.1(8.8,9.5)$ \\
\hline 6 days/week & 32,193 & $6.2(5.9,6.4)$ & 17,855 & $7.1(6.7,7.5)$ & 14,338 & $5.3(5.0,5.7)$ \\
\hline Every day & 89,381 & $17.2(16.9,17.4)$ & 55,557 & $22.1(21.7,22.4)$ & 33,824 & $12.6(12.2,12.9)$ \\
\hline
\end{tabular}

Abbreviation: HDI, Human development index; PA, physical activity.

In Table 2, the prevalence of PA levels stratified by age groups is presented. The prevalence of the lowest level of PA (never) increases from 11 to 12 years to 16 to 17 years among boys and girls. Overall, the biggest increase is from 11 to 12 years to 13 to 15 years. From the ages of 13 to 15 to 16 to 17 years, the increase is slight. On the other hand, the prevalence of engaging in PA every day decreases over the age from $28.2 \%$ (95\% CI: $27.4,29.0$ ) to $21.2 \%$ (95\% CI: $20.3,22.0)$ among boys, and from $19.4 \%$ (95\% CI: $18.5,20.2)$ to $11.1 \%(95 \%$ CI: 10.1, 12.0) among girls. The prevalence of PA 3 to 4 days/week and 5 to 6 days/week also decreases with age among boys and girls. 
Table 2. Physical activity levels according to age, stratified by sex.

\begin{tabular}{cccc}
\hline & \multicolumn{3}{c}{ Age } \\
\cline { 2 - 4 } & $\mathbf{1 1 - 1 2}$ Years & $\mathbf{1 3 - 1 5}$ Years & 16-17 Years \\
\hline Boys & $\%(95 \% \mathrm{CI})$ & $\%(95 \% \mathrm{CI})$ & $\%(95 \% \mathrm{CI})$ \\
\hline Never & $6.7(5.8,7.7)$ & $16.0(15.6,16.5)$ & $17.9(17.0,18.9)$ \\
1-2 days/week & $16.7(15.8,17.6)$ & $23.6(23.2,24.0)$ & $28.0(27.1,28.9)$ \\
3-4 days/week & $24.9(24.1,25.8)$ & $22.0(21.6,22.4)$ & $19.1(18.2,20.0)$ \\
$5-6$ days/week & $23.4(22.6,24.3)$ & $17.5(17.0,17.9)$ & $13.8(12.9,14.7)$ \\
Every day & $28.2(27.4,29.0)$ & $20.9(20.5,21.3)$ & $21.2(20.3,22.0)$ \\
\hline Girls & $\%(95 \% \mathrm{CI})$ & $\%(95 \% \mathrm{CI})$ & $\%(95 \% \mathrm{CI})$ \\
\hline Never & $8.4(7.5,9.4)$ & $23.1(22.7,23.5)$ & $25.6(24.7,26.5)$ \\
1-2 days/week & $21.9(21.0,22.7)$ & $30.0(29.6,30.4)$ & $35.7(34.8,36.5)$ \\
3-4 days/week & $28.3(27.5,29.1)$ & $21.9(21.5,22.3)$ & $17.3(16.4,18.3)$ \\
$5-6$ days/week & $22.1(21.2,22.9)$ & $13.6(13.2,14.0)$ & $10.4(9.4,11.3)$ \\
Every day & $19.4(18.5,20.2)$ & $11.4(11.0,11.8)$ & $11.1(10.1,12.0)$ \\
\hline
\end{tabular}

The levels of PA according to the HDI is presented in Table 3. The prevalence of never engaging in PA of at least $60 \mathrm{~min} /$ day is more pronounced in countries with the lowest HDI. For boys and girls, the prevalence decreases moderately among low HDI countries to high HDI countries. However, there is a very sharp decrease in countries with very high HDI. In boys and girls who engaged in PA 5 to 6 days/week, the prevalence increases from the countries with the lowest HDI to the countries with the highest HDI. For PA every day, boys from countries with very high HDI presented a slightly higher prevalence $(24.7 \%$, 95\% CI: $24.2,25.2)$ compared to those from countries with high, middle and low HDI. For the girls, no clear pattern was observed. The highest prevalence for achieving PA recommended levels were from the countries with the lowest HDI $(16.5 \%, 95 \%$ CI: $14.8,18.2)$ and highest HDI (14.7\%, 95\% CI: 14.2, 15.2).

Table 3. Physical activity levels according to the human development index, stratified by sex.

\begin{tabular}{ccccc}
\hline & \multicolumn{4}{c}{ Human Development Index } \\
\cline { 2 - 5 } & Low & Middle & High & Very High \\
\hline Boys & $\%(95 \% \mathrm{CI})$ & $\%(95 \% \mathrm{CI})$ & $\%(95 \% \mathrm{CI})$ & $\%(95 \% \mathrm{CI})$ \\
\hline Never & $30.2(28.7,31.7)$ & $25.3(24.5,26.2)$ & $19.1(18.6,19.7)$ & $5.9(5.3,6.5)$ \\
1-2 days/week & $32.1(30.7,33.6)$ & $31.9(31.1,32.7)$ & $24.2(23.7,24.8)$ & $18.2(17.7,18.7)$ \\
3-4 days/week & $12.0(10.3,13.7)$ & $14.8(13.9,15.7)$ & $20.7(20.1,21.3)$ & $26.9(26.4,27.4)$ \\
5-6 days/week & $6.8(5.0,8.6)$ & $9.6(8.6,10.5)$ & $15.1(14.5,15.7)$ & $24.3(23.8,24.8)$ \\
Every day & $18.9(17.3,20.5)$ & $18.4(17.5,19.3)$ & $20.8(20.2,21.4)$ & $24.7(24.2,25.2)$ \\
\hline Girls & $\%(95 \% \mathrm{CI})$ & $\%(95 \% \mathrm{CI})$ & $\%(95 \% \mathrm{CI})$ & $\%(95 \% \mathrm{CI})$ \\
\hline Never & $36.4(34.9,37.9)$ & $30.2(29.5,31.0)$ & $31.0(30.5,31.6)$ & $7.8(7.2,8.4)$ \\
1-2 days/week & $30.9(29.3,32.4)$ & $35.6(34.9,36.3)$ & $29.9(29.3,30.4)$ & $26.6(26.1,27.1)$ \\
3-4 days/week & $9.8(8.0,11.6)$ & $14.0(13.1,14.8)$ & $18.3(17.7,18.9)$ & $30.1(29.6,30.6)$ \\
5-6 days/week & $6.4(4.6,8.2)$ & $8.3(7.5,9.2)$ & $10.8(10.2,11.4)$ & $20.7(20.2,21.3)$ \\
Every day & $16.5(14.8,18.2)$ & $11.8(11.0,12.7)$ & $10.0(9.4,10.6)$ & $14.7(14.2,15.2)$ \\
\hline
\end{tabular}

The prevalence of PA levels according to regions is presented in Table 4. Across all regions, girls were less active than boys. For boys and girls, the lowest prevalence of never doing PA was observed in Central and Eastern Europe, and in high-income Western countries. Conversely, South Asian countries presented the highest prevalence. The regions that showed the highest prevalence of never doing PA are the same that showed the highest prevalence for doing PA daily. Among girls, the results were quite different. Girls from South Asia were the ones that had the highest prevalence in achieving PA recommended levels. 
Table 4. Physical activity levels according to regions, stratified by sex.

\begin{tabular}{|c|c|c|c|c|c|c|c|c|}
\hline & \multicolumn{8}{|c|}{ Region } \\
\hline & $\begin{array}{c}\text { Central and } \\
\text { Eastern Europe }\end{array}$ & $\begin{array}{c}\text { Central Asia, } \\
\text { Middle East, } \\
\text { and North } \\
\text { Africa }\end{array}$ & $\begin{array}{c}\text { East and } \\
\text { Southeast Asia }\end{array}$ & $\begin{array}{c}\text { High-Income } \\
\text { Western } \\
\text { Countries }\end{array}$ & Oceania & $\begin{array}{c}\text { Sub-Saharan } \\
\text { Africa }\end{array}$ & South Asia & $\begin{array}{l}\text { Latin America } \\
\text { and Caribbean }\end{array}$ \\
\hline Boys & $\%(95 \% \mathrm{CI})$ & $\%(95 \% \mathrm{CI})$ & $\%(95 \% \mathrm{CI})$ & $\%(95 \%$ CI $)$ & $\%(95 \% \mathrm{CI})$ & $\%(95 \% \mathrm{CI})$ & $\%(95 \% \mathrm{CI})$ & $\%(95 \% \mathrm{CI})$ \\
\hline Never & $3.3(2.4,4.3)$ & $19.0(17.8,20.3)$ & $23.5(22.4,24.6)$ & $3.5(2.7,4.2)$ & $26.4(24.2,28.6)$ & $27.5(25.7,29.3)$ & $35.1(33.1,37.2)$ & $22.3(21.7,22.9)$ \\
\hline 1-2 days/week & $15.0(14.1,15.9)$ & $32.4(31.3,33.6)$ & $34.0(33.0,35.0)$ & $16.2(15.5,16.9)$ & $31.0(28.8,33.2)$ & $30.9(29.2,32.6)$ & $28.6(26.4,30.7)$ & $25.4(24.9,26.0)$ \\
\hline 3-4 days/week & $27.2(26.3,28.0)$ & $18.1(16.8,19.4)$ & $16.0(14.9,17.1)$ & $28.8(28.1,29.4)$ & $13.9(11.5,16.4)$ & $15.1(13.2,17.0)$ & $9.8(7.4,12.3)$ & $19.2(18.6,19.8)$ \\
\hline 5-6 days/week & $25.9(25.1,26.7)$ & $8.7(7.3,10.0)$ & $8.7(7.5,9.9)$ & $26.8(26.2,27.5)$ & $12.9(10.5,15.4)$ & $8.2(6.2,10.2)$ & $6.3(3.8,8.8)$ & $14.0(13.3,14.6)$ \\
\hline Every day & $28.6(27.8,29.4)$ & $21.7(20.5,23.0)$ & $17.8(16.6,18.9)$ & $24.7(24.0,25.4)$ & $15.7(13.3,18.1)$ & $18.3(16.4,20.1)$ & $20.2(17.9,22.5)$ & $19.1(18.5,19.7)$ \\
\hline Girls & $\%(95 \%$ CI $)$ & $\%(95 \%$ CI $)$ & $\%(95 \% \mathrm{CI})$ & $\%(95 \%$ CI $)$ & $\%(95 \% \mathrm{CI})$ & $\%(95 \% \mathrm{CI})$ & $\%(95 \% \mathrm{CI})$ & $\%(95 \%$ CI $)$ \\
\hline Never & $4.5(3.6,5.4)$ & $26.3(25.2,27.5)$ & $26.8(25.8,27.8)$ & $4.4(3.6,5.1)$ & $30.0(28.0,32.0)$ & $34.9(33.3,36.4)$ & $37.0(34.7,39.4)$ & $35.6(35.1,36.2)$ \\
\hline 1-2 days/week & $21.7(20.9,22.6)$ & $39.2(38.2,40.3)$ & $44.1(43.2,45.0)$ & $24.2(23.6,24.9)$ & $31.3(29.4,33.3)$ & $33.5(31.9,35.1)$ & $22.6(20.0,25.2)$ & $29.9(29.3,30.4)$ \\
\hline 3-4 days/week & $31.9(31.1,32.7)$ & $15.2(13.9,16.4)$ & $15.3(14.2,16.4)$ & $33.6(33.0,34.2)$ & $13.8(11.6,16.0)$ & $13.1(11.3,14.9)$ & $8.0(5.1,10.8)$ & $15.5(14.9,16.1)$ \\
\hline 5-6 days/week & $23.4(22.6,24.2)$ & $6.8(5.6,8.1)$ & $6.0(4.8,7.1)$ & $23.4(22.7,24.0)$ & $11.5(9.3,13.7)$ & $6.0(4.1,7.9)$ & $8.4(5.5,11.3)$ & $9.6(8.9,10.2)$ \\
\hline Every day & $18.5(17.6,19.3)$ & $12.5(11.2,13.7)$ & $7.9(6.8,9.0)$ & $14.4(13.7,15.1)$ & $13.4(11.2,15.6)$ & $12.5(10.7,14.4)$ & $24.0(21.4,26.6)$ & $9.4(8.7,10.0)$ \\
\hline
\end{tabular}


Cambodia (7.3\%, 95\% CI: 3.8, 10.8), Philippines (7.7, 95\% CI: 5.6, 9.7), Sudan (8.8, 95\% CI: 4.7, 12.9), Timor-Leste $(8.9,95 \%$ CI: 5.5, 12.3), and Afghanistan (10.1, 95\% CI: 6.1, 14.1) were the countries with the lowest prevalence of sufficient PA. Three of those countries are from East and Southeast Asia (Cambodia, Philippines, and Timor-Leste). From the other regions, the countries with the lowest prevalence of sufficient PA were Italy from the High-income Western countries (10.3\%, 95\% CI: 7.3, 13.2), Syria from Central Asia, Middle East, and North Africa (10.6\%, 95\% CI: 7.2, 13.9), Vanuatu from Oceania (11\%, 95\% CI: 5.4, 16.6), Curaçao from Latin America and the Caribbean (11.7, 95\% CI: 7.7, 15.8), Mauritania from Sub-Sharan Africa (12.1\%, 95\% CI: 7.9, 16.3), and Estonia from Central and Eastern Europe $(16.4 \%, 95 \%$ CI: 13.6, 19.3). Countries that presented the highest prevalence of PA every day, achieving the PA recommended levels, were Finland (27.9, 95\% CI: 25.7, 30.0), Albania (28.0, 95\% CI: 25.6, 30.3), Bulgaria (28.6, 95\% CI: 26.2, 31.0), the United States (32.3, 95\% CI: 30.9, 33.8), and Bangladesh (48.2, 95\% CI: 45.6, 50.8). Considering PA $\geq 5$ days per week, countries that presented the highest prevalence were Iceland (53.7, 95\% CI: 52.3, 55.0), the United States (56.7, 95\% CI: 55.6, 57.9), Canada (58.0, 95\% CI: 56.9, 59.1), Finland (58.7, 95\% CI: 57.0, 60.3), and Bangladesh (59.7, 95\% CI: 57.4, 62.1). Table A1 shows the physical activity levels by regions and countries (Appendix A).

\section{Discussion}

This study found that the prevalence of adolescents doing sufficient PA was low. Less than $20 \%$ of the adolescents engaged in PA every day and almost $20 \%$ never engaged in PA. Regardless of the country, region, HDI, or age group, adolescent girls revealed consistently lower PA levels than boys. These results reinforce the urgent need for worldwide international, national, and local agencies to take action to promote PA, especially among girls. Interventions conducted for improving girls' PA have shown small but significant effects [16]. Successful strategies for changing girls' PA were found for interventions that were theory-driven, multi-component in design, school-based, and that also offer physical education, which addresses the unique needs of girls and targeting girls only $[16,17]$. Engagement with young people, such as active listening to their voices, has also been identified as an important way of developing meaningful PA opportunities [18,19].

The scaling up of implementing known effective policies and programs as well as social marketing campaigns combined with community-based interventions have been suggested for increasing PA in adolescents, particularly in girls [6]. Overall, recent evidence of PA trend studies indicates that the percentage of physically active adolescent girls has not increased over the years $[6,20]$. This suggests that programs and policies to promote PA among adolescent girls are having limited success. Nevertheless, in another trend study, an increase in the prevalence of PA among girls has been found aged 11 to 15 years from 10 out of 32 countries [21]. Understanding why these countries succeed in improving girls' PA levels might be important in helping to define and implement more effective policies and strategies.

Another major finding from our study was that sufficient PA decreases with age among boys and girls, which is in line with previous literature [22]. In our study, a decrease with age seems to be similar in both sexes, i.e., around $7 \%$ to $8 \%$ from 11 to 12 years to 16 to 17 years. However, the biggest decrease in meeting the PA levels is from 11 to 12 years to 13 to 15 years. Therefore, early adolescence seems to be a critical period for either preventing the PA decline or promoting PA. Furthermore, considering that PA decline starts at ages 6 to 7 [22], that PA may track from childhood to adolescence [23], that childhood is a critical period for developing the basic motor competencies [24], and the fact that in our study 11-year-old boys and girls had already low levels of PA, there is a need for a greater emphasis on promoting PA from an early age (and not only in adolescence).

It was found that the prevalence of never engaging in PA of at least 60 min per day was more pronounced in countries with the lowest HDI and decreased for countries with higher HDI. Additionally, the prevalence of engaging in PA 5 to 6 days/week was higher in countries with the highest HDI. A similar trend was observed among low- and middle-income countries, where increased HDI values were associated with decreased levels of physical inactivity [25]. In contrast, the analyses based on the 
2018 Activity Report Card for children and youth showed higher PA levels in the low and medium HDI countries [8]. Additionally, the prevalence of insufficient PA in analysis with adults was more than twice as high in high-income countries as in low-income countries [26]. Finally, less economically developed countries had the lowest prevalence of physical inactivity, while physical inactivity was more prevalent among the most developed economic countries [7]. The different findings between studies can be in part explained based on compositional differences in the study sample and PA measurement method. For instance, in Activity Report Cards the PA assessment used indicators that included 5 behaviors (overall PA, organized sports participation, active play, active transportation, sedentary behavior) [8], while for the present study a single-item indicator of total PA was used. Furthermore, the fact that PA also varies across countries suggests that the factors influencing PA lie mostly at the national community level [26]. Nevertheless, these conflicting results highlight an area for future research to better understand the factors affecting the relationship between PA and HDI.

The results of this investigation have several implications for national and international public health policies. Overall, this investigation reinforces the World Health Organization's recommendation for countries to develop or update national policy and implementation plans on PA [27] as findings suggest an urgent need to improve PA levels among adolescents. One critical aspect is the necessity of allocating the necessary political priority and resources to enable the implementation of PA policies [6].

For every single country, age and sex were factors associated with PA participation. In this regard, national public health policies aiming to promote PA should also focus on reducing the gap between sexes and age groups. Thus, effectively promoting PA among adolescents requires identifying, understanding, and intervening on the causes and inequities [6]. Furthermore, because of the low levels of PA, countries would benefit and should invest in the promotion of PA in all its forms (including recreational PA, sports participation, physical education, and active travel) and in all sectors. This multisectoral approach, leading to the involvement of health authorities, schools, sports clubs and federations, regional planners, and political leaders on PA promoting strategies, is considered effective and commended in the WHO Global action plan on PA 2018-2030 [28].

Several limitations of this study are important to mention. Data were collected at the school setting resulting in the exclusion of adolescents that do not attend schools. In addition, data were from adolescents aged 11 to 17 years. However, data from the HBSC survey were collected among those who attended the grades 6,8 , and 10 . Thus, adolescents from the HBSC survey were mostly aged 11 , 13 , and 15 years, whereas the GSHS focuses on adolescents aged 13 to 17 years. Furthermore, data were self-reported and subject to bias. Despite large samples used in each national or regional survey, self-report was the most feasible methodology and is still the backbone of surveillance studies [29].

\section{Conclusions}

Monitoring PA levels in adolescents allows the identification of specific needs and inequities within and between countries, and consequently promotes informed decisions and actions. Findings show that worldwide PA levels among adolescents are low, as $14.9 \%$ of boys and $21.2 \%$ of girls report to never practice PA, and that the situations get worse with aging. Identifying and understanding the main factors related to the insufficient and decreased PA levels, will permit international and national public health entities to define priority actions and policies against physical inactivity. Reducing the gender gap, specifically improving girls' PA levels should be considered a priority in public health-related actions. This process, initiated with national or regional surveillance of PA, ultimately aims to improve PA levels and promotes healthy lifestyles among adolescents as well as carrying them forward into adulthood.

Author Contributions: Conceptualization, A.M. and M.P.; methodology, M.P. and D.H.-N.; software, A.M. and J.M.; formal analysis, A.M., J.M., Y.D. and D.M.I.S.; investigation, A.M. and M.P.; resources, M.G.d.M.; data curation, D.H.-N. and M.P.; writing—original draft preparation, A.M., M.P.; writing-review and editing, J.M.; visualization, Y.D., D.M.I.S. and M.G.d.M.; supervision, M.G.d.M. All authors have read and agreed to the published version of the manuscript. 
Funding: This research received no external funding.

Acknowledgments: The authors would like to thank all the adolescents who participated in the study. The authors would also like to thank the researchers who made the databases available through free access.

Conflicts of Interest: The authors declare no conflict of interest.

\section{Appendix A}

Table A1. Physical activity levels by region and countries.

\begin{tabular}{|c|c|c|c|c|c|c|}
\hline \multirow{2}{*}{ Region } & \multirow{2}{*}{ Country } & \multicolumn{5}{|c|}{ Physical Activity (\%) } \\
\hline & & Never & $\begin{array}{c}1-2 \\
\text { Days/Week }\end{array}$ & $\begin{array}{c}3-4 \\
\text { Days/Week }\end{array}$ & $\begin{array}{c}5-6 \\
\text { Days/Week }\end{array}$ & $\begin{array}{c}\text { Every } \\
\text { Day }\end{array}$ \\
\hline \multirow{17}{*}{$\begin{array}{c}\text { Central and } \\
\text { eastern } \\
\text { Europe }\end{array}$} & Albania & 3.1 & 21.0 & 30.2 & 17.8 & 28.0 \\
\hline & Bulgaria & 4.5 & 18.4 & 26.5 & 22.0 & 28.6 \\
\hline & Canada & 3.7 & 12.7 & 25.6 & 33.0 & 25.0 \\
\hline & Croatia & 2.6 & 17.7 & 27.5 & 26.5 & 25.6 \\
\hline & Czech Republic & 2.5 & 17.7 & 32.9 & 25.7 & 21.3 \\
\hline & Estonia & 3.6 & 21.1 & 35.1 & 23.8 & 16.4 \\
\hline & Greenland & 10.7 & 31.7 & 22.7 & 16.8 & 18.0 \\
\hline & Hungary & 5.1 & 18.8 & 29.0 & 24.5 & 22.6 \\
\hline & Latvia & 3.1 & 20.8 & 33.6 & 24.0 & 18.4 \\
\hline & Macedonia & 2.7 & 14.7 & 31.1 & 24.6 & 26.9 \\
\hline & Moldova & 3.7 & 23.8 & 24.6 & 21.8 & 26.0 \\
\hline & Poland & 4.3 & 16.3 & 27.9 & 27.6 & 24.0 \\
\hline & Romania & 9.6 & 26.8 & 23.7 & 18.7 & 21.3 \\
\hline & Russia & 5.0 & 19.8 & 38.6 & 18.7 & 17.9 \\
\hline & Slovakia & 3.2 & 17.8 & 29.6 & 24.1 & 25.3 \\
\hline & Slovenia & 3.1 & 20.1 & 32.4 & 25.9 & 18.5 \\
\hline & Ukraine & 4.5 & 16.5 & 32.0 & 20.8 & 26.3 \\
\hline \multirow{13}{*}{$\begin{array}{l}\text { Central Asia, } \\
\text { Middle East, } \\
\text { and north } \\
\text { Africa }\end{array}$} & Algeria & 11.4 & 53.7 & 14.0 & 5.8 & 15.1 \\
\hline & Armenia & 4.9 & 19.9 & 34.6 & 17.8 & 22.9 \\
\hline & Egypt & 30.4 & 40.9 & 10.7 & 3.6 & 14.5 \\
\hline & Iraq & 37.1 & 31.4 & 11.9 & 5.0 & 14.6 \\
\hline & Kuwait & 22.6 & 32.8 & 19.5 & 9.6 & 15.5 \\
\hline & Lebanon & 16.3 & 29.3 & 18.1 & 11.7 & 24.6 \\
\hline & Mongolia & 13.9 & 30.4 & 19.5 & 11.0 & 25.2 \\
\hline & Morocco & 22.0 & 49.0 & 11.0 & 4.8 & 13.1 \\
\hline & Oman & 27.9 & 36.8 & 19.5 & 4.1 & 11.7 \\
\hline & Palestinian territory & 33.8 & 33.3 & 11.4 & 5.8 & 15.7 \\
\hline & Syria & 35.6 & 39.2 & 10.7 & 3.9 & 10.6 \\
\hline & United Arab Emirates & 19.0 & 32.8 & 20.3 & 9.9 & 18.0 \\
\hline & Yemen & 38.8 & 35.2 & 9.7 & 4.4 & 11.9 \\
\hline \multirow{8}{*}{$\begin{array}{c}\text { East and } \\
\text { southeast } \\
\text { Asia }\end{array}$} & Brunei Darussalam & 16.4 & 38.9 & 23.5 & 9.2 & 12.1 \\
\hline & Cambodia & 38.2 & 42.8 & 8.3 & 3.3 & 7.3 \\
\hline & Laos & 24.3 & 43.5 & 11.5 & 5.5 & 15.2 \\
\hline & Malasya & 17.9 & 39.0 & 19.1 & 9.1 & 14.9 \\
\hline & Philippines & 44.3 & 34.6 & 8.8 & 4.6 & 7.7 \\
\hline & Thailand & 23.7 & 38.7 & 17.8 & 8.1 & 11.9 \\
\hline & Timor-Leste & 30.2 & 49.6 & 8.2 & 3.2 & 8.9 \\
\hline & Viet Nam & 27.6 & 38.8 & 14.2 & 6.2 & 13.1 \\
\hline
\end{tabular}


Table A1. Cont.

\begin{tabular}{|c|c|c|c|c|c|c|}
\hline \multirow{2}{*}{ Region } & \multirow{2}{*}{ Country } & \multicolumn{5}{|c|}{ Physical Activity (\%) } \\
\hline & & Never & $\begin{array}{c}1-2 \\
\text { Days/Week }\end{array}$ & $\begin{array}{c}3-4 \\
\text { Days/Week }\end{array}$ & $\begin{array}{c}5-6 \\
\text { Days/Week }\end{array}$ & $\begin{array}{c}\text { Every } \\
\text { Day }\end{array}$ \\
\hline \multirow{23}{*}{$\begin{array}{l}\text { High-income } \\
\text { western } \\
\text { countries }\end{array}$} & Austria & 2.4 & 20.1 & 32.9 & 25.0 & 19.4 \\
\hline & Belgium & 3.6 & 23.3 & 34.1 & 22.5 & 16.6 \\
\hline & Denmark & 4.9 & 23.1 & 35.6 & 23.2 & 13.1 \\
\hline & England & 2.4 & 17.1 & 33.5 & 28.5 & 18.5 \\
\hline & Finland & 1.8 & 11.3 & 28.2 & 30.8 & 27.9 \\
\hline & France & 4.8 & 27.2 & 35.0 & 20.1 & 12.9 \\
\hline & Germany & 3.7 & 22.7 & 37.4 & 20.8 & 15.4 \\
\hline & Greece & 6.5 & 23.2 & 34.3 & 22.6 & 13.4 \\
\hline & Iceland & 4.6 & 13.9 & 27.9 & 31.2 & 22.4 \\
\hline & Ireland & 3.4 & 14.3 & 29.6 & 29.1 & 23.6 \\
\hline & Israel & 16.3 & 34.9 & 24.3 & 12.1 & 12.4 \\
\hline & Italy & 8.3 & 28.7 & 33.8 & 18.9 & 10.3 \\
\hline & Luxembourg & 2.8 & 19.6 & 30.4 & 24.4 & 22.8 \\
\hline & Malta & 7.3 & 24.3 & 28.2 & 22.3 & 17.9 \\
\hline & Netherlands & 3.2 & 15.5 & 31.8 & 31.3 & 18.3 \\
\hline & Norway & 3.0 & 16.6 & 33.7 & 27.9 & 18.9 \\
\hline & Portugal & 3.6 & 28.7 & 32.9 & 19.0 & 15.8 \\
\hline & Scotland & 3.1 & 16.7 & 34.0 & 28.7 & 17.5 \\
\hline & Spain & 3.0 & 15.0 & 30.2 & 25.9 & 25.9 \\
\hline & Sweden & 4.5 & 19.2 & 34.4 & 27.8 & 14.1 \\
\hline & Switzerland & 2.1 & 18.4 & 36.0 & 29.1 & 14.4 \\
\hline & United States & & 22.2 & 21.1 & 24.4 & 32.3 \\
\hline & Wales & 4.0 & 20.6 & 35.5 & 23.5 & 16.3 \\
\hline \multirow{11}{*}{ Oceania } & Fiji & 26.0 & 27.3 & 14.7 & 13.5 & 18.5 \\
\hline & Kiribati & 28.0 & 32.9 & 12.5 & 8.8 & 17.8 \\
\hline & Nauru & 49.2 & 19.3 & 11.0 & 7.9 & 12.6 \\
\hline & Niue & 27.7 & 21.9 & 19.0 & 19.0 & 12.4 \\
\hline & Samoa & 28.3 & 32.5 & 18.3 & 9.0 & 11.8 \\
\hline & Solomon Islands & 18.9 & 38.9 & 15.4 & 10.5 & 16.4 \\
\hline & Tokelau & 33.1 & 17.4 & 11.6 & 14.0 & 24.0 \\
\hline & Tonga & 32.4 & 31.1 & 11.6 & 11.1 & 13.8 \\
\hline & Tuvalu & 47.0 & 26.7 & 9.4 & 5.4 & 11.6 \\
\hline & Vanuatu & 17.7 & 29.2 & 8.1 & 34.0 & 11.0 \\
\hline & Wallis and Futuna & 20.7 & 37.3 & 19.5 & 9.1 & 13.3 \\
\hline \multirow{8}{*}{$\begin{array}{c}\text { Sub-Sharan } \\
\text { Africa }\end{array}$} & Ghana & 32.7 & 32.6 & 14.8 & 6.9 & 13.0 \\
\hline & Mauritania & 41.1 & 34.3 & 8.0 & 4.5 & 12.1 \\
\hline & Mauritius & 18.0 & 31.3 & 19.1 & 12.4 & 19.2 \\
\hline & Mozambique & 21.4 & 45.4 & 13.8 & 6.0 & 13.4 \\
\hline & Namibia & 41.4 & 26.3 & 11.8 & 6.5 & 14.1 \\
\hline & Seychelles & 31.3 & 28.1 & 16.5 & 7.2 & 16.9 \\
\hline & Sudan & 33.0 & 40.5 & 14.2 & 3.5 & 8.8 \\
\hline & Tanzania & 27.3 & 30.5 & 14.0 & 8.1 & 20.2 \\
\hline \multirow{3}{*}{ South Asia } & Afghanistan & 30.1 & 36.5 & 14.7 & 8.6 & 10.1 \\
\hline & Bangladesh & 23.1 & 9.9 & 7.3 & 11.6 & 48.2 \\
\hline & Pakistan & 45.7 & 30.8 & 7.7 & 4.1 & 11.7 \\
\hline
\end{tabular}


Table A1. Cont.

\begin{tabular}{|c|c|c|c|c|c|c|}
\hline \multirow{2}{*}{ Region } & \multirow{2}{*}{ Country } & \multicolumn{5}{|c|}{ Physical Activity (\%) } \\
\hline & & Never & $\begin{array}{c}1-2 \\
\text { Days/Week }\end{array}$ & $\begin{array}{c}\text { 3-4 } \\
\text { Days/Week }\end{array}$ & $\begin{array}{c}5-6 \\
\text { Days/Week }\end{array}$ & $\begin{array}{c}\text { Every } \\
\text { Day }\end{array}$ \\
\hline \multirow{22}{*}{$\begin{array}{c}\text { Latin } \\
\text { America and } \\
\text { Caribbean }\end{array}$} & Antiqua and Barbuda & 30.1 & 21.1 & 16.2 & 9.8 & 22.7 \\
\hline & Argentina & 15.1 & 35.0 & 20.2 & 11.5 & 18.2 \\
\hline & Bahamas & 31.9 & 28.8 & 15.8 & 8.9 & 14.6 \\
\hline & Barbados & 28.1 & 27.6 & 16.7 & 9.4 & 18.3 \\
\hline & Belize & 32.4 & 21.8 & 15.4 & 9.5 & 20.9 \\
\hline & Bolivia & 22.3 & 38.9 & 15.9 & 9.4 & 13.5 \\
\hline & Brasil & 34.2 & 24.1 & 16.8 & 12.9 & 12.0 \\
\hline & British Virgin Islands & 31.3 & 26.9 & 16.2 & 7.7 & 18.0 \\
\hline & Chile & 16.5 & 32.0 & 23.9 & 12.4 & 15.2 \\
\hline & Costa Rica & 18.0 & 35.1 & 19.2 & 9.6 & 18.1 \\
\hline & Curaçao & 32.3 & 31.9 & 16.5 & 7.6 & 11.7 \\
\hline & Dominica & 35.1 & 28.7 & 13.3 & 6.8 & 16.1 \\
\hline & El Salvador & 28.6 & 35.4 & 13.7 & 8.5 & 13.8 \\
\hline & Guatemala & 26.9 & 35.9 & 15.9 & 7.2 & 14.0 \\
\hline & Guyana & 39.2 & 26.2 & 11.8 & 7.2 & 15.6 \\
\hline & Honduras & 28.9 & 37.3 & 12.3 & 5.8 & 15.7 \\
\hline & Mexico & 17.5 & 38.5 & 16.8 & 9.3 & 17.8 \\
\hline & Peru & 17.8 & 37.7 & 19.3 & 9.8 & 15.4 \\
\hline & Saint Kitts and Nevis & 32.7 & 26.9 & 15.3 & 7.2 & 18.0 \\
\hline & Suriname & 26.0 & 30.8 & 16.6 & 7.4 & 19.2 \\
\hline & Trinidad and Tobago & 29.8 & 26.4 & 15.6 & 8.3 & 19.9 \\
\hline & Uruguay & 20.7 & 31.0 & 20.7 & 12.4 & 15.2 \\
\hline
\end{tabular}

\section{References}

1. USDHHS. 2018 Physical Activity Guidelines Advisory Committee Scientific Report; U.S. Department of Health and Human Services: Washington, DC, USA, 2018.

2. Rodriguez-Ayllon, M.; Cadenas-Sanchez, C.; Estevez-Lopez, F.; Munoz, N.E.; Mora-Gonzalez, J.; Migueles, J.H.; Molina-Garcia, P.; Henriksson, H.; Mena-Molina, A.; Martinez-Vizcaino, V.; et al. Role of Physical Activity and Sedentary Behavior in the Mental Health of Preschoolers, Children and Adolescents: A Systematic Review and Meta-Analysis. Sports Med. 2019, 49, 1383-1410. [CrossRef] [PubMed]

3. Reiner, M.; Niermann, C.; Jekauc, D.; Woll, A. Long-term health benefits of physical activity-a systematic review of longitudinal studies. BMC Public Health 2013, 13, 813. [CrossRef] [PubMed]

4. WHO. Global Recommendations on Physical Activity for Health; World Health Organization: Geneva, Switzerland, 2010.

5. Wen, C.P.; Wai, J.P.; Tsai, M.K.; Yang, Y.C.; Cheng, T.Y.; Lee, M.C.; Chan, H.T.; Tsao, C.K.; Tsai, S.P.; Wu, X. Minimum amount of physical activity for reduced mortality and extended life expectancy: A prospective cohort study. Lancet 2011, 378, 1244-1253. [CrossRef]

6. Guthold, R.; Stevens, G.A.; Riley, L.M.; Bull, F.C. Global trends in insufficient physical activity among adolescents: A pooled analysis of 298 population-based surveys with 1.6 million participants. Lancet Child. Adolesc. Health 2020, 4, 23-35. [CrossRef]

7. Dumith, S.C.; Hallal, P.C.; Reis, R.S.; Kohl, H.W., 3rd. Worldwide prevalence of physical inactivity and its association with human development index in 76 countries. Prev. Med. 2011, 53, 24-28. [CrossRef]

8. Aubert, S.; Barnes, J.D.; Abdeta, C.; Abi Nader, P.; Adeniyi, A.F.; Aguilar-Farias, N.; Andrade Tenesaca, D.S.; Bhawra, J.; Brazo-Sayavera, J.; Cardon, G.; et al. Global Matrix 3.0 Physical Activity Report Card Grades for Children and Youth: Results and Analysis from 49 Countries. J. Phys. Act. Health 2018, 15, S251-S273. [CrossRef]

9. Ridgers, N.D.; Timperio, A.; Crawford, D.; Salmon, J. Validity of a brief self-report instrument for assessing compliance with physical activity guidelines amongst adolescents. J. Sci. Med. Sport 2012, 15, 136-141. [CrossRef] 
10. Prochaska, J.J.; Sallis, J.F.; Long, B. A physical activity screening measure for use with adolescents in primary care. Arch. Pediatr. Adolesc. Med. 2001, 155, 554-559. [CrossRef]

11. Marques, A.; Bordado, J.; Tesler, R.; Demetriou, Y.; Sturm, D.J.; de Matos, M.G. A composite measure of healthy lifestyle: A study from 38 countries and regions from Europe and North America, from the Health Behavior in School-Aged Children survey. Am. J. Hum. Biol. 2020, e23419. [CrossRef]

12. Marques, A.; Loureiro, N.; Avelar-Rosa, B.; Naia, A.; Matos, M.G. Adolescents' healthy lifestyle. J. Pediatr. (Rio. J.) 2020, 96, 217-224. [CrossRef]

13. Marques, A.; Demetriou, Y.; Tesler, R.; Gouveia, E.R.; Peralta, M.; Matos, M.G. Healthy Lifestyle in Children and Adolescents and Its Association with Subjective Health Complaints: Findings from 37 Countries and Regions from the HBSC Study. Int. J. Environ. Res. Public Health 2019, 16, 3292. [CrossRef] [PubMed]

14. World Bank Country Classification. Available online: https://datahelpdesk.worldbank.org/knowledgebase/ topics/19280-country-classification (accessed on 1 December 2019).

15. UNDP. Human Development Report 2016. Human Development for Everyone; United Nations Development Programme: New York, NY, USA, 2016.

16. Owen, M.B.; Curry, W.B.; Kerner, C.; Newson, L.; Fairclough, S.J. The effectiveness of school-based physical activity interventions for adolescent girls: A systematic review and meta-analysis. Prev. Med. 2017, 105, 237-249. [CrossRef] [PubMed]

17. Camacho-Minano, M.J.; LaVoi, N.M.; Barr-Anderson, D.J. Interventions to promote physical activity among young and adolescent girls: A systematic review. Health Educ. Res. 2011, 26, 1025-1049. [CrossRef] [PubMed]

18. Martins, J.; Marques, A.; Sarmento, H.; Carreiro da Costa, F. Adolescents' perspectives on the barriers and facilitators of physical activity: A systematic review of qualitative studies. Health Educ. Res. 2015, 30, 742-755. [CrossRef] [PubMed]

19. Corr, M.; McSharry, J.; Murtagh, E.M. Adolescent girls' perceptions of physical activity: A systematic review of qualitative studies. Am. J. Health Promot. 2019, 33, 806-819. [CrossRef]

20. Booth, V.M.; Rowlands, A.V.; Dollman, J. Physical activity temporal trends among children and adolescents. J. Sci. Med. Sport 2015, 18, 418-425. [CrossRef]

21. Kalman, M.; Inchley, J.; Sigmundova, D.; Iannotti, R.J.; Tynjala, J.A.; Hamrik, Z.; Haug, E.; Bucksch, J. Secular trends in moderate-to-vigorous physical activity in 32 countries from 2002 to 2010: A cross-national perspective. Eur. J. Public Health 2015, 25 (Suppl. 2), 37-40. [CrossRef]

22. Farooq, M.A.; Parkinson, K.N.; Adamson, A.J.; Pearce, M.S.; Reilly, J.K.; Hughes, A.R.; Janssen, X.; Basterfield, L.; Reilly, J.J. Timing of the decline in physical activity in childhood and adolescence: Gateshead Millennium Cohort Study. Br. J. Sports Med. 2018, 52, 1002-1006. [CrossRef]

23. Telama, R.; Yang, X.; Leskinen, E.; Kankaanpaa, A.; Hirvensalo, M.; Tammelin, T.; Viikari, J.S.; Raitakari, O.T. Tracking of physical activity from early childhood through youth into adulthood. Med. Sci. Sports Exerc. 2014, 46, 955-962. [CrossRef]

24. Gallahue, D.L.; Ozmun, J.C.; Goodway, J.D. Understanding Motor Development: Infants, Children, Adolescent and Adults; McGraw-Hill: Boston, MA, USA, 2012.

25. Atkinson, K.; Lowe, S.; Moore, S. Human development, occupational structure and physical inactivity among 47 low and middle income countries. Prev. Med. Rep. 2016, 3, 40-45. [CrossRef]

26. Guthold, R.; Stevens, G.A.; Riley, L.M.; Bull, F.C. Worldwide trends in insufficient physical activity from 2001 to 2016: A pooled analysis of 358 population-based surveys with 1.9 million participants. Lancet Glob. Health 2018, 6, e1077-e1086. [CrossRef]

27. WHO. ACTIVE: A Technical Package for Increasing Physical Activity; World Health Organization: Geneva, Switzerland, 2018.

28. WHO. Global Action Plan on Physical Activity 2018-2030: More Active People for a Healthier World; World Health Organization: Geneva, Switzerland, 2018.

29. Pedisic, Z.; Bauman, A. Accelerometer-based measures in physical activity surveillance: Current practices and issues. Br. J. Sports Med. 2015, 49, 219-223. [CrossRef] [PubMed]

(C) 2020 by the authors. Licensee MDPI, Basel, Switzerland. This article is an open access article distributed under the terms and conditions of the Creative Commons Attribution (CC BY) license (http://creativecommons.org/licenses/by/4.0/). 